\title{
History and folklore of basmati rice
}

\author{
Subhash Chander Ahuja ${ }^{1}$, Uma Ahuja ${ }^{2 *}$ and Siddharth Ahuja ${ }^{3}$ \\ ${ }^{1}$ Retired Plant Pathologist, Rice Research Station, CCS Haryana Agricultural University, Kaul, Haryana - 136021 \\ ${ }^{2}$ Retired Professor, Genetics and Plant Breeding, College of Agriculture, CCS Haryana Agricultural University, Kaul, \\ Haryana - 136021
}

${ }^{3}$ Department of Pharmacology, Shaheed Hasan Khan Mewati Government Medical College, Nalhar, Mewat, Haryana - 122107

\section{Article history}

Received: 08 Nov., 2019

Revised: 13 Dec., 2019

Accepted: 19 Dec., 2019

\section{Citation}

Ahuja SC, U Ahuja and S Ahuja. 2019 History and folklore of basmati rice. Journal of Cereal Research 11(3): 206-214. http:// doi.org/10.25174/2249-4065/2019/95207

*Corresponding author

Email:va5419@yahoo.co.uk

(C) Society for Advancement of Wheat and Barley Research

\section{Introduction}

Among cereal crops, rice is unique because of its adaptability to various edaphic and climatic conditions. Over the long period of its cultivation coupled with conscious and continuous selection subsequently by man for his diverse quality preferences has resulted into numerous varieties. Like its cultivators (fair coloured farmers from Kashmir to dark coloured in South to brown in between) rice comes in all shapes, sizes and colours (Ahuja et al., 2000). The grain colour varies from white, brown, red, purple to black; length ranges from extra long, long, medium to small and their shape from fine, slender, round, coarse to medium. Basmati, like other rice varieties, has red, black and golden husk variants, though at present only golden husked basmati is famous. All the three variants are still grown in Champaran area of Bihar state (Ahuja et al., 2001).

\begin{abstract}
Basmati is an important food item as well as export commodity. Indian subcontinent has been bestowed by Mother Nature for this exclusive food and production area. Three colour variants have been known in Basmati as in many other rice of addition to its special cooking quality and medicinal value, it is a sought after donor in number of breeding programmes. So far, the earliest reported record of word Basmati is that of Heer Ranjha of Waris Shah (1766). This review presents additional records on word Basmati, historical area of cultivation, folk songs, folk tales, proverbs, associated with Basmati in states of Himachal Pradesh, Punjab, Uttarakhand, UP and Bihar. Basmati is not an ambrosial food item but has been used to convey as an adjective too. In addition it finds place in prayer offered to God. Of all the states, Uttarakhand seems to be proud and the richest source of Basmati folklore. This review on basis of large number of folkloric records corroborate with Dr. Khush's postulation of Himalyan belt as Centre of diversity and spread of aromatic rices.
\end{abstract}

Keywords: Basmati, etymology, folklore, folksongs, folktales

Rato (Red husked) Basmati is still cultivated in Tarai area of Nepal.

Another special feature with rice is aroma/scent. Rice is classified into aromatic and non-aromatic. In India, earlier to era of high yielding varieties about 300 traditional scented varieties were grown in specific niches of various states. Scented varieties differ in size, shape, colour, cooking quality and possess distinct aroma of their own (Ahuja et al., 2009). Basmati group surpasses all other scented rices in cooking and eating qualities and has found wider acceptance all over the world. The special quality of Basmati rice is attributed to unique combination of soil, water and climate, besides the inherent genetics governing these features (Siddiq et al., 2012). Requirement of specific agro-climatic conditions restricts extent of its area of cultivation. Major area of basmati cultivation 
lies between Punjab of Pakistan and erstwhile Punjab (Punjab, Haryana, and Himachal), J \&K and western U.P. In addition it is grown in some parts of Rajasthan (Kota), Bihar, Bengal and M.P.

\section{What is Basmati?}

Even a common man would swear Basmati to be the rice with special taste. Scientists describe it as a tall, low-yielding variety with beautiful, long slender and lustrous grains, possessing exquisite scent, sweet ambrosial taste, soft texture, delicate curvature, high kernel elongation with least breadth wise swelling, intact non sticking kernels, giving a feel and soft touch of fresh butter on the eater's tongue against dry and rough touch of a non-basmati variety (Thakrar and Ahuja, 1993). These features fit into the description of a beautiful maid's matrimonial, appearing in any Indian newspaper or that of a beauty queen.

Basmati has been the subject and debate and discussion of many seminars and numerous symposia and adorned pages of books, magazines, and websites and newspapers world over (Singh et al., 2006). This is one of the scented varieties which was the cause of controversy and furore in agriculture history over which countries argued. Governments, traders, exporters, farmers, scientists and public split hair; trying to protect what each one believed was theirs'. Companies in the West took out patents and trademarks, using novel definitions and measurements for this sought after cereal variety. Defying the world's stagnant rice exports trade, it showed upward trends. It caught the fancy of scientists and occupied their research priority in countries even in distant lands of USA, Japan, the Philippines and Australia. In homeland, it was a nightmare for rice scientists who spent more than 30 precious years of their research in solving and defining the secrets of intrinsic beauty of this slender grain. It drew attention of the bio-technologists who developed DNA tests for its authentication. It brought prosperity, and improved the well-being of all those who protected, nurtured and nourished this wonderful and unique strain of rice (Singh et al., 2006).

Basmati has medicinal value too. Though rice contains high levels of complex carbohydrates and is categorized as a high glycemic index food but Basmati has a low glycemic index (Rhoades, 2003). Basmati is high in Fe and $\mathrm{Zn}$, and helps in their bio-availability (adsorption). Basmati rice makes a metallothionein-like protein that is rich in cystine which aids in iron absorption; gene controlling this activity is being used in the development of Fe-rich rice through biotechnology (Chaudhary and Tran, 2001).

\section{Etymology of word 'Basmati'}

There has been controversy on the etymology of the word "Basmati". Publications from Pakistan (Asfaq et al., 2015) described it as Bas (aroma) + mati (mind) or smell that soothes mind. However, it is established and widely accepted that the Basmati word comprises of two Sanskrit syllables: ' Vaas, means fragrance and matup means possessing (already ingrained). The latter part $(u p)$ of the suffix matup is deleted prior to combining two syllables Vaas and mat (means that possess the preceding quality) on lines of Srimat (i.e. Srimat would imply "one who possesses the grace") (Ahuja et al., 2001). Upadhyay Krishan Dev, a scholar of Bhojpuri Folklore and collector of folksongs, mentioned that Dehraduni rice emitting scent/aroma and is called both Basmati and Vasmati (which means endowed with scent) (Upadhyay, 1991).

\subsection{Historical growing areas}

Though, at present only light husked Basmati dominates the scene, old records show dominance of red husked basmati. It was grown on vast area. Ain-i-Akbari records cultivation of Mushkin in subahs (provinces) of Lahore, Multan, Allahabad, Oudh, Delhi, Agra, Ajmer, and Raisen area of Malwa Subah (MP). In Haryana, it was grown in Panipat (Karnal, Safidon, and Ganor), Jajjhar, Rohtak, Gohana, Hisar, Hansi, Meham, Sirsa, and Rewari (Jarrett, 1949; Ahuja et al., 2001). Mushkin among all the varieties cultivated during Akbar's time fetched the highest price (Blochmann, 1989). It was reported as a red husked paddy that ripens quickly has small white fragrant rice pleasant to taste.

In North India, interest in rice research was generated after the appointment of Cereal Scientist in 1925 and collection of basmati types from various regions. Basmati 370, along with basmati types were released for cultivation in erstwhile Punjab in 1935. Basmati 370 subsequently replaced other colored types due to consumer preference. Ram Dhan Singh, the man behind the release of Basmati 370 writes "It is interesting to note that this group of rices(mushkan) which were once popular is now disappearing from cultivation and replaced by Basmati rices" (Anonymous, 1942). The red husked variant paddy known as Mushkan/ Mushkin or Lal Basmati is comparatively more resistant to storage insects than light colored Basmati and was grown on vast areas (Roberts and Singh, 1951).

Baden-Powell (1892) describing Land record system in Akbar's time, mentioned as footnote 3: "shalay mushkeen" is the Persian word shal-i-mushkin or scented rice, one of the best kinds (bansmatti). This statement makes clear that mushkin grown in Akbar's time was a kind of Basmati. Ain used the shal-i-mushkin, instead of the word Basmati. Races of Rice in India (RORII; Anonymous, 1911) records scented mushkin, mushkan and mushkun, respectively, in Lahore, Sialkot and Syadwala districts (Anonymous, 1911). Thus, mushkan 
which was grown in Akbar's time as Shalay mushkin was popular until the release and spread of basmatis in 1940 's, is clear from the record of Roberts and Singh (1951). With passage of time word muskin got changed to mushkan under local Punjabi effect. Basmati has been pronounced differently in various areas, RORII listed 17 kinds of spellings in different growing areas as bansmatee, bansmattee, bannsmatti, bansmoti, bansmatti, bansmutti, bansmutty, bansmati, bansmuttee, basmatee, basmathi, basmattee, basmatti, basmaty, basmuti, basmuttee and basmutti. Grierson (1885) in 'Bihar Peasant Life' referred it as basmatiya and Dave (1949) called this land race in Madhya Pradesh as basmatia and basmoti. Mushkin is still cultivated in Bundelkhand of Uttar Pradesh (Vandana Shiva and Kunwar, 2005).

Exact place of origin and diversification is lost in antiquity. However, Basmati spread to far of places due to love of royals and found place in the gifts among nobles who were possessive of the grain. Bara (Peshawari Basmati) could only be grown under king's supervision near the fortress of Bara in Peshawar. Ordinary people were not allowed in the proximity of the fields, and taking even a grain was punishable offence. This rice formed part of the gifts sent to Maharaja Ranjit Singh in 1822 by Yar Mohhamad Khan in the hope propitiating him (Watt, 1901; Ahuja et al., 1995). Similarly, Tapovan Basmati in Uttarakhand was grown under the decree of the king of Tehri. The entire Tapovan village used to grow basmati for the consumption of royal family. Later the Mahant (Head Priest) of the local temple acquired the right (Singh et al., 2001). In Central India, the Nawab of Hyderabad was so fond of Basmati rice that he ordered it to be grown in his kingdom (Ahuja et al., 2001). Similarly, under the requirement and desire of Nawab of Hyderabad, a selection of Amritsari variety (Basmati), HR 12 was developed in the erstwhile State of Hyderabad.

The British too appreciated the fine grained long rices of North West Provinces and took these to the eastern part of India. Dr. Collins sent samples of Bara rice from the valley of Shaik Khan (opposite the fort of Bara about $9 \mathrm{~km}$. southwest of Peshawar) to Dr. Bolivia, the then Honorary Secretary, Agricultural and Horticultural Society of Oudh (Watt, 1901; Ahuja et al., 2001). Likewise, Mr. JH Oliver, the Deputy Commissioner, Sirsa in the mid-1850s, introduced basmati and Peshawari to Sirsa from the said area (Baden-Powell, 1868; Ahuja et al., 2008). Peshawari is a familiar trade house word in West Bengal. Similarly, Basmati was brought to Dehradun Valley by Amir Dost Mohammed Khan, in the mid-19th century ruler of Afghanistan, when he was exiled there by British in 1840 (Ahuja et al., 2008). The Prime Minister of Iran, Mirza Agha Khan, took Sadri, equivalent of Basmati, to Iran from India (Shaida, 1992). There also three variants are called as dum zard (light husk colour), dum siah (black) and dum surkh (red).

\subsection{History of the word basmati}

Though records of scented or fragrant rices are available in literature, historical accounts and travelogues and the earliest record appears to be that referred in Ramayana (Shaw, 1988). Scented rices were described by Charaka and Sushruta (Ahuja et al., 2008).

Till today, the earliest known record of the word "Basmati" is that in the great saga of Heer Ranjha of Waris Shah (in circa 1766) (Ahuja et al., 1995; Ahuja and Ahuja, 2006; Thakrar and Ahuja, 1993). However, another reference traced is in Awadi dialect of Hindi, in the epic poem "Padmaval" by Malik Mohamad Jayasi (year 1540) (Shirreff, 1944) a contemporary of Goswami Tulsi Dass of Ram Charit Manas.

The following traced reference in English on word Basmati puts, record 238 years prior to earlier known record in the epic poem of Heer Ranjha in 1766. Charles in 2013 published the reports of William (of Widford), deputed on Royal Mission to India in 1528, during the reign of Mughal King, Humayun and recorded "We had then a sumptuous meal, a banquet instead. Dish after dish came on the table, rich biryanis were followed by fragrant pilaos, followed by roasted meat and fried fish served with heaps of perfumed long grained basmati rice" Kamran (a brother of Humayun) said that he had the rice basmati from Punjab; and the Patliputra long grain rice grown on the Yamuna-Ganga alluvial doab, but Basmati was better" (Charles, 2013). Thus two types of Basmati were known during Mughal period. White Basmati in Mughal period (1528) was known to grow in Punjab and Patliputra of which that of Punjab was considered better (Charles, 2013). Red basmati (Mushkin) was more popular and used in Emperor's kitchen (Jarrett, 1949) than the long grain white Basmati.

Another historical record of this period is that of 1556, when Akbar attacked the fort of Kangra (now in Himachal Pradesh) in Punjab, and was told about four famous things of Kangra as the surgery of making new noses, the treatment of eye diseases, Basmati rice and the strong fort (Cunningham, 1875).

Of all the growing areas, Basmati of Kangra was considered of very good quality and was long grain and of great export value. Dr. Dickson in 1840 refers to it in Imperial Gazetteer and writes that the Kangra district has a great export of rice, of which the most esteemed kind is the Basmati (Kapoor 2002). Mittal (1986) writing on British Administration in Kumaon during 1815-1947, mentioned best varieties as Basmati, Hansraj and Sal. 
Montgomery (1838) mentioned about the rice grown in Bihar as "All the transplanted rice is rather finer, than what that grows in Bengal. Sukhdas, the finest, is very white, and its smell, although inferior to the Basmati even of Patna, is still very agreeable. The transplanted rice is all fine, such as is usually sold as that of Patna ; but the very finest called Basmati does not exceed one quarter of the whole, and is not of such an excellent flavor as the Basmati (pregnant with perfume) of Bareli".

By 1845 , the word Basmati, for the first time, acquired a place in a Dictionary of Indian Terms intended to help members of British Raj to adjust to their new and unfamiliar surroundings (Morton, 2004). After that reference on Basmati is found in Cyclopedia (Balfor, 1871). 'A Rural and Agricultural Glossary of N.W. Provinces and Oudh' (Crooke, 1888) refers to a quotation (Carnegy, 1877) on Basmati of Allahabad, UP.

RORII (Anonymous, 1911) lists Basmati growing in Punjab, Kashmir, Bihar, and Bengal. Graham (1914) classified rices of the Central Province and refers to Basmati as long grained rice. In a later report, Dave classified 719 varieties grown in Central Provinces for their 21 plant morphological characters and 11 grain characters. He listed nine Basmatia and Basmoti both of early duration (ED) and medium duration (MD). MD Basmatia grew in Bilaspur, Katghora while the ED in Balaghat, Mahasmund, Sihora and Murwara areas. ED Basmoti was grown in Garhchiroli, while MD in Bilaspur and Gondia areas. Of these only one each of Basmatia and Basmoti were scented (Dave, 1949).

\section{Basmati Folklore}

Being sustainer of life, rice has developed a deep rooted relation with culture of people of India and in rice growing Asian countries (Ahuja et al., 2010). A number of rice varieties make their appearance in folk literature of Indian states (Ahuja and Ahuja, 2010; Ahuja et al., 1997; De, 2014). Like rice itself, Basmati has embedded itself in the daily life of people. Basmati rice shows its presence in folklore of Kumaoni, Garhwali, Maithaili, Awadi, Himachali, Dogri, Hindi, Punjabi, Urdu and Nepalese languages. It symbolises purity, whiteness, prosperity, humility and grace.

Basmati appears in short stories, one-act plays, novels, poems and even in prayers for God. A number of short stories and novels depict characters engrossed or fascinated by the sweet smell and beauty. Girija Prashad Mathur, a well-known poet and a connoisseur of nature compares moonlight with Basmati rice (Chaudhari, 1993). Even presence of a very small piece of stone in mouth along with Basmati bhat is considered as a torture (Bhatta, 1989).
Like other important/ essential things of life, it also represents the universal duality. Its possession/ affording convey the richness or prosperity and it's lacking means otherwise, as conveyed in folk tale about Gaura Parvati (Godling). She (Godling) was moved by the wretched condition of a poor young woman friend who was unable to procure food for her children, places Sathi and Savam underneath her pillow. Kuber Nath Ray, Gyanpeeth Awardee remarked that the poor composer of the folk tale could not think of Basmati even at this time, and further said that Gaura Parvati, being a friend of poor did not afford Basmati for herself. Poor man's Godling, too, is poor (Ray, 2012).

In Bihar, Uttar Pradesh and Nepal number of ladies owe their name to Basmati. Celebrity writers like Munshi Prem Chand, Ayodhya Singh Upadhya 'Hariaudh', Shivani, Phanishwar Nath Renu, Mahashweta Devi and Sailesh Matiyani have named female characters as Basmati/Basmatiya in stories and novels. Basmatia has been used as an adjective Basmatia Hasina denoting beautiful girl with sweet fragrance (Jayaswala, 2007). Basmati di mehak goes as the title of a story by Navtej Singh in Punjabi.

The followers of Jain sect in prayer to God, Chander Prabhu recite: Tandul dhawal vasmati ke laun, charano mein a-ksat punj carhau. A-ksyapna hove prapt, araj meri sun lije. They pray that their request be heard and offer unbroken white Basmati rice for getting freedom from cycle of rebirth.

\subsection{Basmati Folktale}

In a story entitled 'Basmati', describes pitiful position of a poor farmer who raised basmati with timely hard work and hoped/imagined to offer Basmati to his sonin- law, but at the end of season could get only a fistful of barongar rice (Bacchan, 2009).

\section{Basmati Cultivation - As a medium for Teaching}

Swami Parmanand has nicely and precisely used Basmati cultivation as a medium to teach followers the secret to achieve peace and God. A successful basmati crop demands eagerness, intention, good seed, fertile fields, weeds, proper care, and irrigation at proper time. Swami associated and compared it to cultivating relationship with God that equally requires intention, eagerness, truthfulness, hard work, honesty, freedom, treating all humans as equal, weeding out bad habits and cultivating good behaviour to achieve the Almighty (Parmanand, 2008).

\subsection{Basmati in Poems}

A poetess remembers her mother through the medium of Basmati. Aise hi basi rahti thi, Mehak tumhare aspas; 
Suddh ublate Basmati ki. Just so stayed unending, Aroma around you, Of boiling pure Basmati (Jain, 1999). Bhavani Prasad Misra, a known Hindi poet, addresses his life partner: Basmati dhan hai, Kapuri ek pan hai, Jasaliya hai gehun; Basmati is a paddy Jasaliya is wheat, kapuri is pan (Misra, 2002).

Pokhar par ke basmati ki, Gandh ke tane bane; Nahar kinare ke bargad ki, Chamv dhare sirhane; Deh jurati hari ghas ki. From across the pool, Wave of Basmati aroma so, cool! A young poetess in a poem conveys that she was always taught to yield or submit, to be humble and courteous like the panicles of Basmati "Mujhe sikhaya gaya tha hamesa, Jhukna vinayshil hona; Jis tarah basmati ki baliyan, Hoti hain Jhuki Jhuki"(Chamoli, 2012; https:// www.hindisamay.com/content/3478/1/)4/11/2019).

Unke kheton ke lahrate masuri sarju bavan narender bhadaiaur jal-magn dhano ki gandh, mujh tak pahumc rahi thi; Aur sayad pahar ke anjani jariya aur basmati ki khusbu unke nasaputom mem pahumc chuki thi (Joshi, 2012; http:// pahleebar.wordpress.com/page/5/). Aroma touched me, Arising from thy water- deep paddy; And that from waving fields of Mahsuri Narender Bhadai Sarju Bavan; And may be aroma of Hilly Jariya and Basmati Anjani touched him.

\subsection{Basmati folklore of various States}

\section{Uttarakhand}

Basmati appears in mythological tales, songs and proverbs of Uttarakhand. According to a Puranic tale it is believed that Lord Shiva and Parvati who in earlier birth were male and female birds took rebirth as Bali Nanda and Bal Ishwar. After their marriage they settled in Kailash Himalaya. One day Bali Nanda preyed to Bal Ishwar to get seed of Jeera Basmati. White golden sparrow was assigned with the duty of bringing seed of Jeera Basmati. The bird flew to Nandu Mehri'flower garden and brought the seeds (Pokharia, 2009).

A number of Folkdance songs of fairies are prevalent in Tehri Garhwal. A tale of seven Rawat (a caste) sisters is well known. Huniya goddling kidnapped the seven sisters, they live on Khaint hill. The song means as: The seven girls were caught in heavy storm, and they started thinking of way outs and thought to go to kharsali area (in Tihri) with flat land they say 'we will tie patka (waist cloth) of kandali (Bichhu ghas, Urtica dioica) on waist, or we go to Gangar area (area near the Ganga banks) there Jiri Basmati is grown (Nautiyal, 1981).

The Jagar Dance Songs in Garhwal related to Pandavs are mainly based on Mahabharata but at some place there is a love story of Arjun and Vasudatta, a nag kanya. Arjun saw her in dream and left sleeping Draupadi and reached naglok. There Arjun saw Vasudatta and felt her beauty as:
"Naunivalo namo, jeeri valo pind, Suvarn taruni dehi, Candan ki lata; Pai patnyali, amkhi ratanyali, Hira ki si jot,Jon si udot": may be translated as: she had radiance of gold, heavenly beauty, soft like butter, beautiful like morsel of Basmati rice, thin legs, sightly red eyes, brilliant like a diamond, and bright like moon" (Nautiyal, 1981).

Ay s vai syarai mani hunchau chhori shalai jamalau, jai syara mani hunchau Basmati hansraj (Pokharia et al., 2005). Our fields raise shali rices of jamol, Basmati and hansraj. In Agrakhal of Tihri Garhwal, farmers are prosperous due to cultivation of ginger and there goes a saying "Sow Ginger and eat Basmati". Being prosperous they afford and eat Basmati, hence the saying.

From the Badiyar region, there is a folk tale and song relating Basmati, Jeero Jhamko. It is a long tale narrating to human sacrifice for constructing a water canal for good rice harvesting (Baabulkar, 1964). Jeero means Basmati rice and Jhamko means good crop.

In Garhwal and Kumaon of Uttarakhand, boiled rice (bhat) is favourite food and Basmati suits well in its preparation, as is apparent in the proverb: "caval ache kahe to Ramjavan, Bhat acha kahe to jiri ka, Basmati ka" (Cataka, 2001).

"Pat bhalo chhau bhalo chhau kelri ko, Bhat bhalo chhau bhalo chhau Basmati ko; Hat bhalo chau bhalo chho mayeri ko bhalo chhau" (Krishanand, 1971).

During a famine, a person tells his relative that:

"Sona tole rati, dhaula par layu tumuk desi basmati; Pad na bajaro bike Basmati ke bhau". In hilly areas, Bajra is selling at the rate of Basmati, I have brought bag load of Basmati for you (Cataka, 2001).

Basmati in folklore symbolises good luck and prosperity. A Garhwali proverb runs as "Basmati bhag mam, mat kyarak" Basmati rice is either produced due luck or though hard work. A similar Kumaoni proverb runs as "Khawar Basmati ya swar basmati" i.e. If eating Basmati is in one's luck/ destiny, it matters not ones' singing is stable or not (Paliwal, 1985). Another version prevails in Garhwal "Khawar Basmati, shayr basmati" i.e. Progress or downfall depends upon luck. In good luck, the time becomes favorable while under bad luck, conditions turn opposite (Khandpal and Khandpal, 2002).

Another Garhwali proverb tells us "As you sow, so shall you reap" through medium of Basmati as "Buti kodu ar jiri kakhan hoi" i.e. if you have sown kodom (Paspalum scrobiculatum), how can you get Basmati?" A small quote brings out a well-known fact that one cannot find basmati on a high-located place and wisdom in an armpit "Ghaulanu basmati, kharyalun aql karv narai". 


\section{Folk Songs}

Various types of songs as Rupani (transplanting), Jhhodda/Jhorha and Nyoli of Kumaon has mention of basmati. Basmati also appears in Auchhan (Dohad) song relating to mental disposition of a pregnant lady (Pokharia, 2009).

\section{Transplanting song}

While women are busy in transplanting paddy they hear a flute tune. One woman asks another woman about the meaning of flute tune? The woman tells about her husband's message conveyed through the flute for women doing transplanting. 'O! Paddy planters, Do plantation correctly. The Basmati plants should be planted densely. Since you are my sister- in -law (younger brother's wife); I cannot tell you directly how to do perfect transplantation "Bichak ropdarion chhanto ropya sero, basmati ghani ropyan; Toy mung bvari ke jani $n$ bolyan, basmati ghani ropyan; Swamin din bansurya raibar, Basmati ghani ropyan-----

Nyoli Song is sung by grass-cutter ladies, wood-cutters, agricultural labourers, separated wives of soldiers gone to serve faraway places. These are also called Van geet (forest songs). These are two sentence-songs and each sentence contains 14 alphabets. Nyoli is a hill koel (a bird) or a new small verse. Taking Nyoli as stimulus these small verse are sung. "Sag pakayo sagti ko, basmati ko bhat; Jindgi ka car din, Yad rauni Bat" Cooked Sagati vegetable (a hilly vegetable) and Basmati bhat, Life is for days, you remember only words (talks) (Pokharia, 1996). There is another version: "Pital ko thul taul basmati bhat, Jindgi ko car din bat rauni yad" Prepared boiled Basmati rice in a big brass container, Life span is of four days, after any bodies' death you remember only his words, that is what stays back.

\section{Jhhodda/Jhorha song}

Jhorha song is a fair dance song and is referred as Hathjhorha in Nepal and as Khelin Pithoragarh. The fair is held on Baisakhi festival where in men and women dance holding hands. One of such long song runs in 16 lines, the following lines are related in this context:

\section{"Basmati ropanya syara O bamja Jhuprali bamja!" syamgiri ropicha, bamja O Jhuprali bamja.}

In the field for Basmati we have planted Shamgiri nursery O' bamj* Jhabrile bamj tree (Pokharia, 1996)*Quercus leucotrichophora/oak. O bamjaJhuprali bamja! is a refrain of a chorus song.

\section{Folk songs in Himachal Pradesh:}

Himachal Pradesh and adjoining areas of Jammu, Hoshiarpur and Gurdaspur are well known for Basmati growing. In Himachal Pradesh, rice beds are small and sowing is a family affair. Women sing songs while sowing. A number of rice varieties are mentioned in the sowing song as:

We have to sow paddy, my daughter let us go to fields; The drums are playing, come Let us plant the seedling in the beds, we shall plant the Begumi rice in one; Jhona in another and Basmati in next, we shall build firm walls and sow a healthy crop" (Ahuja et al., 1997).

The following song is a dialogue between a young man (who has come from a city) and a Gaddi girl. Attracted towards the beauty of the young girl, asks her to come to his home town but she does not agree. He gives him many types of allurements. Young man promises Gaddi girl that he would stop eating Basmati rice for her sake and would eat ordinary rice like her.

Chori deni Kankan di, Dhin dhin Basmati; Caval dil lana teri saum, Rehna muiye Timbaro (Sharma, 1998).

A Himachal proverb takes us to a dimension of human relationship. A woman says, "Yesterday, I prepared Basmati rice with great love and affection, which I had to eat myself with the sauce of my tears" (Mittoo, 1960).

\subsection{A Proverb from Uttar Pradesh}

Importance of Basmati is evident in Carnegy's quote "Basmati dhan jo gara, Bara admi jo parimit chhara, Unch ke bair, nich ke khae, Ye charon gaye dhol bajaen" conveys the worldly wisdom. "The one who buries Basmati rice, a gentleman who acts dishonourably, the one who quarrels with his superior, and that who eats with inferior- all four denounce themselves by beat of drum" (Crook, 1888).

\section{A saying from Bihar:}

A maiden expresses on unannounced but pleasant arrival of her spouse "Had I known that my beloved is coming, I would have got Basmati rice winnowed". "Jau ham janti piya ki aviya , Basmati chaura chantai rakhti" (Grierson, 1885; Mishra, 1985; Ahuja et al., 2001).

\section{Basmati in Videhi Mithila Poems}

Khait achhi ab basmati caur, Thamhi-tham marait achhi bhaur (Mandal, 2012).

Basmati a jalba gamkat, Laukat madua dhan, Aau sramik jan aau, apan gam dhuri aau (Sriniwas, 2012).

People in Mithila sing in the praise of their land as:

Gyan vicar bhakti bhavak bhandar, Appan Mithila!

Bhog bic yogak nirmal sansar, Appan Mithila!

Ai garib-muda phakane chi;Pathiya bharal marvanak lava;

Basmati cura sandal-mitthkr amaut gali aulni baba; Bharal candera cura dahik bhar, Appan Mithila! (Buch, 
2010). Our Mithila is profusely filled with knowledge, thoughts and devotion. We enjoy beautiful life along with ascetic values. Although now poor we ate butter, anyhow. I ate parched basmati rice mixed with amot sweet. Our Mithila offers a gift of big bamboo palate of parched with curd.

\subsection{Names after Basmati}

In number of widely distant places, in Bihar, Uttar Pradesh and Nepal ladies owe their name to Basmati the sweet smelling, tasty graceful grain. Great writers of Hindi like Munshi Prem Chand, Girija Prasad, Panishwar Nath Renu and a number of other writers named woman character as Basmati in their stories and novels.

Pervasiveness of Basmati is even more than that of rice and coconut having penetrated to world of songs and MP3. Some of recent MP3 of Himachal Pradesh (Basmati re chaodo and Basmati re cavlo moyena by Sharma); 'Basmati Dhan kutto' singer Balveer Rana in Kumoani and Deuda Song "Basmati ko dhan pakaya gharai basai gayo" of western Nepal are popular hits in respective areas. And in Guyanese Dictionary you may find a funny song on Basmati it goes: diz gyal name basmati, she comes from be be, she na wan fuh dance now, she gone and get away, basmati dance gyal. dance down 2 the ground, hold on2 u gangli, and spin it all around (http:// moonsammy.wordpress.com/my-guyana/guyanesedictionary/).

\section{Remarks}

Basmati since long has been appreciated for its ambrosial taste and as favourite food of rich and nobles. It also formed a part of gifts given to nobles for pleasing the guests and rivals. It was available only to elite, nobles and rich of society since the ancient times (scented rices)-and a dream item but out of reach of poor as is evident from the tale (Bacchan, 2009) and the following Punjabi dialogue between Vanjara (grocer/ merchant) and a lady "Vanjaria ve ciriyan da dudh liade, basmati de liade cavle; Sundersohinyae ni, na kithe ciriyan da dudh, na basmati de ni cavle". "The lady asks to bring for her the milk of sparrow and Basmati rice. The grocer answers that the sparrow milk is available nowhere as they don't produce it, neither is Basmati rice".

Review reveals that Basmati has been integral part of folk literature and brings out the richness of folklore of Uttarakhand related to Basmati indicating that Uttarakhand might be centre of diversity of aromatic rice (Basmati) as postulated earlier. Centre of diversity of aromatic rices of Group V is foothills of Himalayas in Indian states of Uttar Pradesh (earlier included Uttarakhand also), Bihar and Nepal. The group V includes world famous high quality Basmati rices of
India and Pakistan along with other long and medium grain aromatic rices (Khush, 2000). Basmati is precious heritage which nature has bestowed so should be protected at any cost.

\section{Acknowledgement}

Authors are thankful to Rashmi Thakrar late and family, of erstwhile Tilda Rice, UK for their constant help, support and guidance in the pursuit of Basmati history and folklore.

\section{References}

1. Ahuja SC and U Ahuja. 2006. Rice in religion and tradition. In: Souvenir of the Second International Rice Congress, 9-12 Oct 2006, New Delhi, India.

2. Ahuja SC and U Ahuja. 2010. Rice in social and cultural life of people. In: SD Sharma (Ed). Rice origin, antiquity and history. CRC Press, Science Publishers, Enfield, USA, pp 39-84.

3. Ahuja SC, DVS Panwar, U Ahuja and KR Gupta. 1995. Basmati rice- The scented pearl. Directorate of Publication, CCS Haryana Agricultural University, Hisar, pp 61.

4. Ahuja SC, DVS Panwar and U Ahuja. 2001. Aromatic rice in Haryana. In: RK Singh and US Singh (Eds). A treatise on scented rices of India. Kalyani Publishers, New Delhi, pp 271-286.

5. Ahuja U, SC Ahuja and R Thakrar. 1997. Rice in folklore of India. Asian Agri- History 1(4): 321-330.

6. Ahuja U, SC Ahuja, R Thakrar and N Shobha Rani. 2008. Scented rices of India. Asian Agri- History 12(4): 267-283.

7. Ahuja U, R Thakrar and SC Ahuja. 2000. Fairs and festivals associated with rice cultivation. Asian AgriHistory 4(1): 39-53.

8. Ahuja U, SS Malik and SC Ahuja. 2009. Diversity in scented rices of India, In (Eds). S Krishnan and DJ Bhat. Plant and fungal diversity and prospecting. Broadway Book Center, Goa, pp99-104.

9. Anonymous 1911. The Agricultural Ledger, 1910. N0. 1. Superintendent Government Printing, India. 607-1200 Printed as Races of Rice in India. Agricole Publishing Academy. New Delhi. pp594.

10. Anonymous 1942. Agriculture Report. Vol. 1, For the year ending $30^{\text {th }}$ June 1941. Punjab, Lahore.

11. Ashfaq M, MS Haider, I Saleem, M Ali, and A Ali. 2015. Basmati-Rice a Class Apart. Journal of Rice Research 3: 156. doi:10.4172/23754338.1000156.

12. Baabulkar ML. 1964. Garhwali loksahitya ka vivechnatmak Ayyadhyan. Hindi Sahitya Sammelan, prayag. pp284. 
13. Bacchan. 2009. Basmati. In. Nai Shuruaat, Kahani Sangrah. Rajpal \& Sons. pp56-66.

14. Baden-Powell BH. 1868. Products of Punjab. Vol. I. \& II. Government Press, Calcutta. India.

15. Baden-Powell BH. 1892. The Land-Systems of British India. Vol. I, Oxford at Clarendon Press.

16. Bhatta P. 1989. Mam Preyasi Aura Patni. Samayika Prakasana. Delhi. pp213.

17. Balfor Edward. 1871. Cyclopedia of India and of Eastern and Southern Asia, Commercial, Industrial and Scientific: Products of the Mineral, Vegetable and Animal Kingdoms, Useful Arts and Manufactures. Vol. 1 (Google eBook). Scottish and Adelphi Press, pp452.

18. Blochmann H. 1989. The Ain- $i$ - Akbari by Abul Fazal Allami. Book II. Low Price Publications, Delhi, India.

19. Buch KJ. 2010. Appan Mithila. Shruthi Prakashan. New Delhi. pp38.

20. Carnegy P. 1877. Kachahri Technicalities, Allahabad.

21. Cataka G. 2001. Garhvali Lokagita Vividha. Taksasila Prakasan, New Delhi. pp237.

22. Chamoli Rekha. 2012. https://www.hindisamay. com/content/3478/1/)4/11/2019

23. Charles RH. 2013. Mission to Distant Land. Author House. 6/21/2013 284 pp e-book ISBN: 9781481798419

24. Chaudhary RC and DV Tran. 2001. Specialty rices of the world - a Prologue. In: Specialty Rices of the World: Breeding, Production, and Marketing (Chaudhary RC and DV Tran, Eds.). FAO, Rome, Italy; and Oxford \& IBH Publishing Co. Pvt. Ltd., New Delhi, India. pp3-14.

25. Chaudhuri S. 1993. Muktasanga (phriesosiesana) Aur Nayi Kavita. Adhunika Pustaka Udyog. pp275.

26. Crooke W. 1888. A Rural and Agricultural Glossary for the NW Provinces and Oudh. Superintendent Govt. Printing, India. Calcutta. pp285.

27. Cunningham Alexander. 1875. Report for year 1872-1874. Office of Supertendant Govt. Printing pp1875.205.

28. Dave BB. 1949. Varieties of Rice Grown in the Central Provinces. Govt. Printing, C. P. and Berar. Nagpur.

29. De Mitu. 2014. Folk Rice Varieties and Cultural Heritage. The Beats of Natural Sciences. 1(1): 7: 1-7.

30. Graham RJD. 1914. Preliminary note on the classification of Rice in the Central Provinces. Memoirs of the Department of Agriculture in India.
Botanical Series Vol.6 (7) Agricultural Research Institute, Pusa, Imperial Dept Agriculture. Thacker, Spink \& Co. Calcutta.

31. Grierson GA. 1885. Behar Peasant Life. Superintendent Government Printing, Calcutta, India. pp223.

32. Sharma K. Basmati re chawlo moyena https://www. youtube.com/watch?v=ajpmbZnRqgY

33. Jain S. 1999. Vaidhavya pp.66. In. Yahi Kahi Par. Sampuran Kaviatayam 2. Vani Prakashan, Delhi. pp136.

34. Jarrett HS. 1949. The Ain- $i$ - Akbari by Abul Fazal Allami. Book II. Low-Price Publications. Delhi. India (Reprint, 1989).

35. Jayaswala CK. 2007. Paltania. Rachnakar Prakashan. Muzafarnagar. Uttar Pradesh. India. pp632.

36. Joshi S. 2012. http://pahleebar.wordpress.com pp5.

37. Khandpal Dipa and Khandpal Lata. 2002. Kumauni Hindi lokoti avm Muhavara Kosh. (Dictionary of Kumauni-Hindi Idioms and Proverbs). Anamika Publishers \& Distributors. New Delhi. pp568.

38. Kapoor Subhodh. 2002. The Indian Encyclopaedia: Kamli-Kyouk Phyu Genesis Publishers Pvt. Ltd. pp8176.

39. Khush GS. 2000. Taxonomy and origin of Rice. 5-14. In Singh et al., (Edt) Aromatic Rices. Oxford \& IBH Publishing Co. Pvt. Ltd. New Delhi Calcutta, pp292.

40. Krishnanand. 1971. Kumaun lok sahitya-Paricayatamak sangraha, Pustak Bhandar, Bareilly. pp425.

41. Mandal R. 2012. Posa Parba: In.Videha Maithilli Padya (Verse). Shruthi Prakashan. pp503.

42. Misra BP. 2002. Basmati Dhan Hai: Bhavani Prashad Misra Rachnavali. Vol. 2. Anamika Publishers and Distributors. New Delhi. pp478.

43. Mishra S. 1985. Aarthik Jivan Ka Chitran. Folklore Hindi Special Number: 1-8.

44. Mittal AK. 1986. British Administration in Kumaon Himalayas - A Historical Study 1815 - 1947. Mittal Publications, New Delhi. 249 pp.

45. Mittoo HK. 1960. Himachal ke Lokgita. Nidesaka, Lok sampark Vibhaga. Simla. pp160.

46. Montgomery M. 1838. The History, Antiquities, Topography, and Statistics of the Eastern India; Vol.1: Bihar (Patna City and Shahabad) London. pp560+54 Appendices.

47. Morton M. 2004. Cupboard of Love 2: A Dictionary of Culinary Curiosities. Insomniac Press. pp337. 
48. Nautiyal SN. 1981. Garhwal ke Lokntritya Geet. Hindi Sahitya Samelan.Paryag. pp484.

49. Paliwal ND. 1985. Kumauni-Hindi Sabdakosh. (Kumauni-Hindi Dictionary). Takshail Prakana. New Delhi. pp416.

50. Pokharia DS. 1996. Kumaon ke lok Geet; MP Adivasi Lok kala Parishad. Bhopal. pp197.

51. Pokharia DS. 2009. Uttarakhand Lok sanskriti aur Sahitya. National Book Trust, India. pp405.

52. Pokharia DS, Tivari Kapila, Misra A. 2005. Kumauni Gatha Rajula Malusahi. MP. Adivasi Lok kala Parishad. Bhopal. pp197.

53. Ray KN. 2012. Chandi Than. Pp. 63-71. In. Priya Neelkanthi, Bharatiya Gyanpith. pp13.

54. Roberts W and SBSK Singh. 1951. A Text Book of Agriculture. Civil and Military Gazzette, Lahore, Pakistan.

55. Rhoades A. 2003. Basmati rice - the quality grain. (www.allcreatures.org).

56. Shaida M. 1992. The Legedary Cusine of Persia. Lieuse Publications Ltd. UK. pp318.

57. Shaw JC. 1988. The Ramayana through Western Eyes. Bangkok: Distributed by D.K. Today Co. pp101.

58. Sharma M. 1998. Tribal Melodies of Himachal Pradesh: Gaddi Folk Music. APH Publishing. New Delhi. pp133.
59. Siddiq EA, LR Vemireddy, and J Nagaraju. 2012. Basmati rices: genetics, breeding and trade. Agricultural Research 1(1):25-36. DOI 10.1007/s40003-011-0011-5

60. Shirreff AG. 1944. Padmavati. Royal Asiatic Soc. Bengal. pp413.

61. Singh RK, Uma Ahuja and SC Ahuja. 2006. Basmati for Prosperity. Indian Farming Oct 2006: 33-36.

62. Singh RK, SC Maini, N Singh, G Singh, HN Singh, Rashmi Rohilla and US Singh. 2001. The Aromatic Rices of Uttar Pradesh and Uttaranchal. In: Singh RK and US Singh (Eds). A Treatise on Scented Rices of India. Kalyani Publishers. New Delhi, pp403-420.

63. Sriniwas SS. 1971. A Poem. In. Thakur Gajinder, Videh Maithli Padhya. Shruti Prakashan, New Delhi. pp503.

64. Swami Paramanand. 2008. Paise se Parmatma ki or. Raj Kamal Praksahan, Delhi. pp174.

65. Thakrar R and SC Ahuja. 1993. Potential and Prospects for Export of Basmati Rice. In: Sidique et al., (Eds). New Frontiers in Rice Research, Directorate of Rice Research, Hyderabad. pp382- 387.

66. Upadhyay KD. 1991. Bhojpuri Lok-Sanskriti, Hindi Sahitya Sammelan, Prayag, Allahabad. pp410.

67. Vandana Shiva and Kunwar J. 2005. Impact of WTO on women in Agriculture. National Commission for Women, New Delhi. pp203.

68. Watt G. 1901. A Dictionary of the Economic Products of India. Vol. V. Cosmo Publications, New Delhi, India. pp676. 